\title{
建設系学科における環境冠学科の設置メカニズム 一高等教育論の視点からー
}

\author{
内山弘美 \\ 非会員 東京大学先端科学技術研究センター博士課程（广153-8904 目黒区駒場 4-6-1）
}

\begin{abstract}
地球環境問題を解決し、サステイナブルな社会を築くために、環境科学という学問分野の構築が必要とされる。し かし、環境科学の研究・教育を行い、環境科学の人材盖成機関であるはずの環境冠学科において、従来から、理念之 現実の䚾離の問题が指摘されてきた。この問題が生じた要因の一つは、環境冠学科の設置の過程にある。従って、本 研究では、国立大学工学系学部の建設系学科に焦点を当て、工学系の抗大過程と科学研究の「ライフサイクル」論の 枠組みを用いて、環境冠学科の設置のメカニズムを解明した。その結果、睘境冠学科の設置は、環境科学だけでなく、 工学系学部の学科構成や学科設置動向を反映していることが明らかになった。
\end{abstract}

Key words: environment-related departments, higher education policy, institutionalization of environmental science, environmental education

\section{1.緒言}

環境問題を解決し、サステイナブルな社会を構築する ためには、環境科学という学問分野を確立することが必 要である。環境科学の制度化の指標の一つは、環境冠学 科 (鲑境を冠する学部・学科・大学院の総称) 注1)である。 環境冠学科の目標は、おおかた環境の研究・教育を行い、 環境問題に対処する人材の養成を行うことである。もち ろん、環境冠学科か環境教育を行っている大学の研究教 育組織の全てではない。しかし、環境冠学科については、 環境接頭 (窃盗) 学科 ${ }^{1)}$ と呼ばれるように、従来から理念 と現実の乘離の問題が指摘されてきた注2 注3) 注4)。この問 題を解決するためには、個々の環境冠学科の理念や教育 内容を吟味することが必要である。しかし、それ以前に、 環境冠学科において理念と現実の乘離の問題が生じた背 景を明らかにすることが必要である。

本論文では、このような問題が生じた背景の一つであ る環境冠学科の設置のメカニズムを明らかにすることを 目的とする。対象とするのは、衛生工学科をルーツとし、 日本で最も早く㻴境冠学科が設置された、国立大学工学 系学部の建設系学科注らである。

\section{2.先行研究の検討及び分析の枠組み}

環境冠学科の諸問題については、1970 年代から主とし て環境科学者によって指摘されてきた 2334)注 9。近年は、 高等教育関係者の間で、学際的な名称の学部・学科の増 加という観点から、国際・人間・情報・福祉と並び、環 境冠学科についても言及されている。しかし、このよう な実践的な関心か強い一方で、環境冠学科を対象にした

\begin{tabular}{|c|c|c|c|}
\hline \multirow[b]{2}{*}{ 大区分 } & \multirow[b]{2}{*}{ 小区分 } & \multirow[b]{2}{*}{ 期間 } & \multirow{2}{*}{$\begin{array}{l}\text { メルク } \\
\text { マール }\end{array}$} \\
\hline & & & \\
\hline 環境科学前史 & & \begin{tabular}{|r|}
$1957-$ \\
1967 \\
\end{tabular} & 衛生工学科 \\
\hline \multirow[t]{2}{*}{$\begin{array}{c}\text { ファースト・ } \\
\text { サイクル }\end{array}$} & $\begin{array}{l}\text { 第一次 } \\
\text { 環境ブーム }\end{array}$ & \begin{tabular}{|r}
$1968-$ \\
1978 \\
\end{tabular} & \multirow[t]{2}{*}{ 環境冠学科 } \\
\hline & 第一次停滞期 & \begin{tabular}{|r|}
$1979-$ \\
1986 \\
\end{tabular} & \\
\hline \multirow[t]{2}{*}{$\begin{array}{l}\text { セカンド・ } \\
\text { サイクル }\end{array}$} & $\begin{array}{l}\text { 第二次 } \\
\text { 環境ブーム }\end{array}$ & 1987- & \multirow[t]{2}{*}{ 環境科学会 } \\
\hline & 第二次停滞期 & & \\
\hline
\end{tabular}

研究は、皆無に近い。

工学系学科の設置については、高等教育論の分野で 様々な研究がなされてきた。とりわけ、高度経済成長期 以降の工学系の拡大過程の研究についての蓄積は多い $5) 6 \%$ 。

本論文では、山田・塚原 ${ }^{8}$ の科学研究の「ライフサイ クル」論の枠組みを用いる。これは、生物のライフサイ クルをアナロジーとして学問分野の形成過程の分析に適 用したものである。まず、新しい学問分野についての需 要が生じ、資源配分 (大学の学科、研究機関のポスト、 研究費) がなされ、その学問分野が制度化し、その後、 長時間を経て不要になった時点でその学問分野は解体さ れるという一連の過程を、ライフサイクルと呼ぶ。

この考え方に準拠して、次のように睘境科学の時代区 分を行った (表一1)。環境科学には、ファースト・サイ クルとセカンド・サイクルという二つのライフサイクル 
が存在する。さらに、各々のライフ・サイクルにおいて

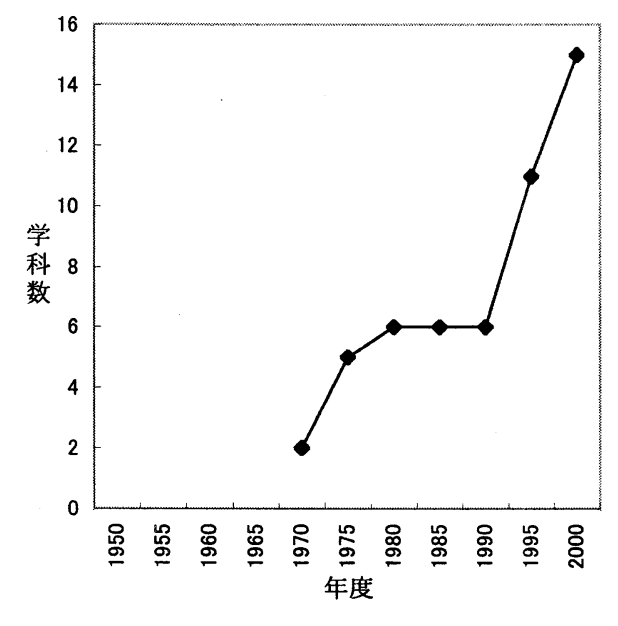

図一1＼cjkstart建設系の環境冠学科数の変遷

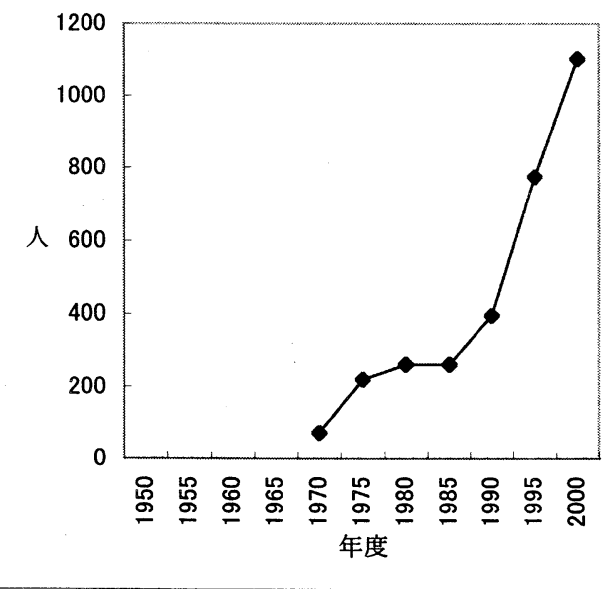

図一2 建設系の環境冠学科定員の変遷

資源配分が盛んになされた時期を環境ブームと定義し、 その後の停滞期と区別した注》注8)。現在は、第二次環境ブ 一ムの段階にある永9。

本論文では、工学系の拡大過程の一連の研究の枠組み を用いて、学科数、定員、学科名称とそのキーワードを 変数にして分析を行い、第一次環境ブームと第二次環境 ブームにおける各々の分析結果の比較を行う。使用する デー夕は、『全国大学一覧』『学校基本調查』各年度版お
よび各大学の大学史等である。

\section{3. 分析 1 -環境冠学科の変遷と社会的背景}

本章では、環境冠学科の設置の背景となった、環境科 学の展開、工学系学部の拡大過程の中で、環境冠学科の 設置動向を概観する。

\section{(1) 環境科学の展開}

本節では、環境科学の時代的趨勢と、環境冠学科の設 置動向の対応関係を明らかにすることを目的とする。

第一次環境ブームは公害の時代であり、同時に、環境 科学の制度化の時代でもあった。公害対策基本法が制定 された翌年の 1968 年に、大阪大学工学部及び九州芸術工 科大学芸術工学部に、最初の環境冠学科が設置された。 1970 年末の公害国会において、公害対策基本法に明示さ れていた「経済との調和条項」が削除され、また、公害 関連の 14 法案が可決・修正された。さらに 1971 年には、 公害・環境問題を総合的に扱う省庁として環境庁が設置 された。1972 年には、国連人間環境会議がストックホル ムで開催されて、人間睘境宣言が採択され、一方、1974 年までに四大公害裁判は、原告勝訴となった。このよう に、1970 年代前半において、公害・環境をめぐる状況は、 急速に展開していった。

公害国会を経て、1970 年代初頭には、国立大学に公害に 関する学科や講座を作るようにという政府からの要請 9) がなされ、1970 年代半ばには環境冠学科の設置ラッシュ となった。とりわけ、1970 年から 1975 年までの期間に嘸 境冠学科数及び定員の増加の加速度のピークが発生した (図一1) (図-2)。

1970 年代半ばまでに、公害関連の法整備がなされ、ま た、公㲅防止技術の開発も企業を中心に進められた結果、 1970 年代後半には、一時期の激甚な公害は一段落した。

一方、二度のオイルショックによる経済の不況ともあ いまって、公害・環境問題に対する社会的関心が低下し、 環境冠学科は設置されなくなった。

第二次環境ブームは、地球環境問題の時代であり、睘 境科学の範囲はグローバル化し、また、人文社会系の領 域にまで拡大している。1980 年代後半に、オゾン層破壊、 酸性雨、熱帯林の破壊を初めとして、様々な鮛境問題が 先進国で話題となり、1980 年代末の冷戦体制の崩壊によ り、軍事問題に代わり地球環境問題が国際問題としてク ローズアップされた。1992 年のリオサミット前後から、 環境問題に対する社会的関心が急速に高まり、それを反 映するかのように、再ひ眔境冠学科の設置ラッシュとな っている。また、建設系の分野においては、1990 年代を 通して、環境に配虑した土木・建設事業が望まれるよう になり、環境負荷の低減や循睘型社会を目指したまちづ くり、国土づくりのための研究が展開している ${ }^{10) 。 そ し ~}$ て、従来の土木工学から環境工学へとシフトする兆しが 
見え

ている 1112) 注 10)。

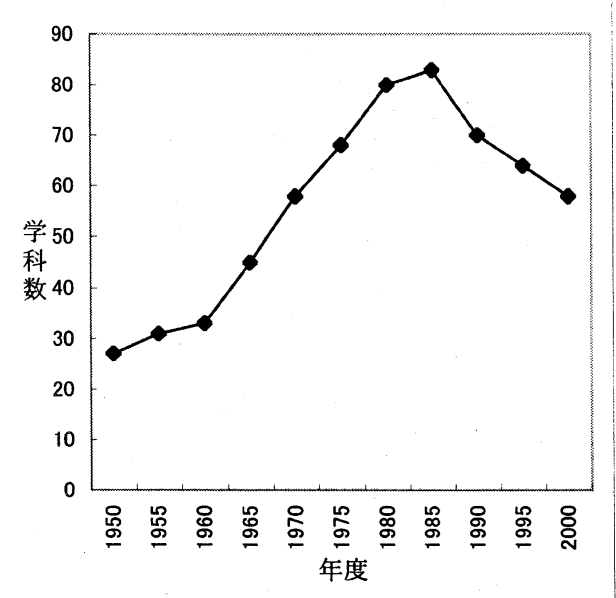

图一3 建設系学科数の变遷

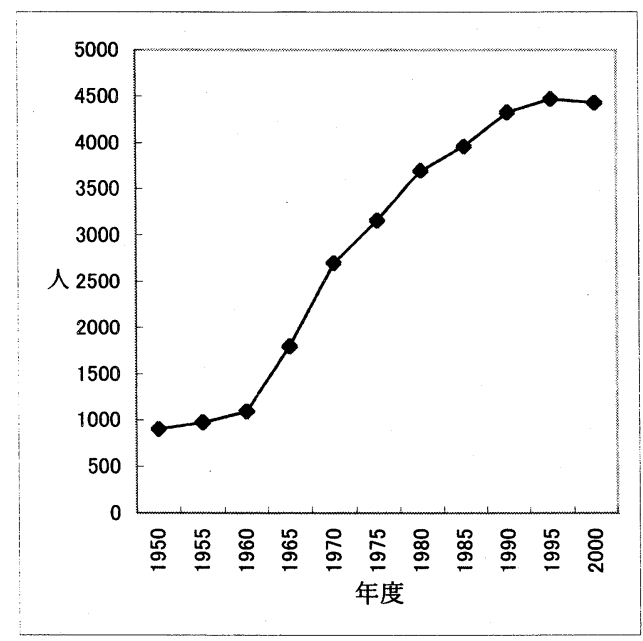

図一4建設系学科定員の変遷

\section{(2) 工学系の拡大過程}

環境冠学科の設置のもう一つの背景は、国立大学工学 系学部の拡大過程である。戦後のめざましい経済復興の 中で、1950 年代、1960 年代を通じて、建設系技術者の 需要は多く、マンパワー政策による理工系学生の拻大政 策の下で ${ }^{1314}$ )、国立大学の建設系学科は、飛躍的な拡大 を遂げた（図一-3）。国立大学工学系学部の拡大の特徴は、 学科規模を 40 人前後に保ったまま、同系統の学科を増設 したことにある ${ }^{15)}$ 。すなわちいわゆる、第二土木工学科、 第三土木工学科を増設することにより、拡大をはかって
きたのである。従って、学科数の増加にほぼ比例して定 員が増加した（図一4）。この拡大のピークがやや鈍り始 めた 1970 年代半ばに、環境冠学科の設置ラッシュが椡来 した。

1970 年代後半以降、環境冠学科の増加は頭打ちになり、 1980 年代に入ると睘境冠学科は設置されなくなった。こ れは 1976 年から 10 年計画で実施された高等教育計画に 起因していた。同計画では、学部・学科の設置は原則抑 制され、特に、後期計画期間中は、工学系学部の設置は されず、新増設された工学系学科は僅かであった。

1985 年に、18 歳人口の急増に対応した臨時定員増及び、 国立大学工学系学部において大講座化・大学科化に伴う 改組再編が開始された。また、再び工学系学部が設置さ れるようになり、1980 年代後半には、国立大学工学系学 部の定員の第二の拡大期となった。また、工学系の改組 再編、すなわち学部・学科のスクラップ・アンド・ビル ドにより、第一次環境ブームに設置された環境冠学科の 多くが姿を消す一方、新たに睘境冠学科が設置されると いう動向が生じてきた。1990 年代に入ると、一県一工学 部政策による工学系学部の新設、教養部改組による工学 系学部・工学系学科の新増設、1990 年代半ば以降の旧帝 大を中心とする大学院重点化ともあいまって、再ひ環境 冠学科の設置ラッシュとなっている。

\section{(3) 結び}

第一次環境ブームにおいて、公害・環境問題に対する 社会的関心の高揚と、建設系学科の整備・拡充の流れの 中で、環境冠学科の設置ラッシュとなった。

第一次停滞期においては、公害・環境問題に対する社 会的関心の低下の時期と、高等教育計画期がほぼ重なっ ており、結果として、環境冠学科の增加が見られなかっ た。

第二次環境ブームにおいては、一方では地球環境問題 に対する社会的関心が高揚し、他方、工学系を始めとし て学部・学科のスクラップ・アンド・ビルドや大学院重 点化の流れの中で、再ひ環境冠学科の設置ラッシュとな っている。

以上をまとめると、工学系学部の挔大・改組再編と公 害・環境問題に対する社会的関心の高揚という、二つの 現象の相乗作用により、第一次環境ブーム・第二次環境 ブームに環境冠学科の設置ラッシュが生じたことが明ら かになった。

\section{4. 分析 2 -学科名称 (1) 学科名称の多様性}

次に、建設系学科の名称に着目する。ここで、建設系 の全学科数を、建設系の学科名称の種類数归11)で割つたも のを同名学科数と呼ぶ。同名学科数は、学科名称の多様 
性を表す指標であり、同名学科数が少ないほど学科名称 がバライエティに富むことを示唆している。

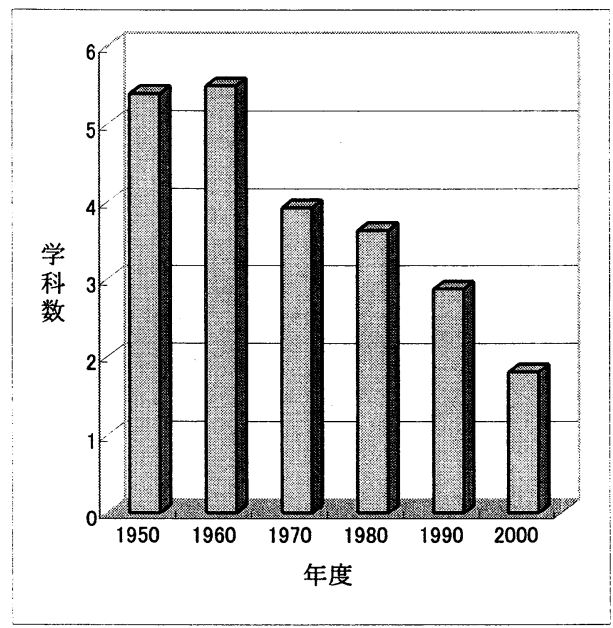

図一，建設系の同名学科数

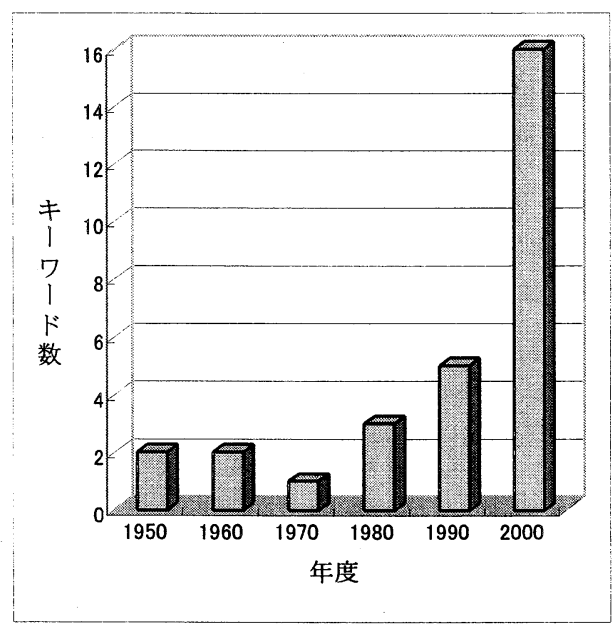

図ー6 建設系の重複キーワード数

建設系の同名学科数の変遷は、図一5のようになる。新 制大学発足直後は 5 6 学科であったが、第一次環境ブー ムには 4 学科程度に減少している。さらに、第二次環境 ブームにおいて減少し、2000 年には 2 学科を割っている。 これは、第一次環境ブームに比べ、第二次環境ブームに おいて建設系の学科名称が多様化していることを示して いる。

(2)キーワードの分析

本論文では、学科名称を構成するそれぞれの単語を、キ
ーワードと呼ぶ。例えば、土木環境工学科であれば、、土 木」と「器境」がキーワードである。建設系の学科名称 の種

表—2 代表的なキーワードと学科名称

\begin{tabular}{|c|c|c|}
\hline キーワード & 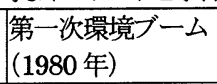 & $\begin{array}{l}\text { 第二次環境ブーム } \\
\text { (2000 年) }\end{array}$ \\
\hline 環境 & $\begin{array}{l}\text { 環境設計 } \\
\text { 環境工 } \\
\text { 住環境 } \\
\text { 環境整備工 } \\
\text { 環境建設工 } \\
\text { 環境計画 }\end{array}$ & $\begin{array}{l}\text { 環境設計 } \\
\text { 環境工 } \\
\text { 環境建設工 } \\
\text { 土木環境工 } \\
\text { 建設環境工 } \\
\text { 環境デザイン } \\
\text { 環境システム } \\
\text { 環境システムエ } \\
\text { 社会環境工 } \\
\text { 地球環境工 } \\
\text { 都市環境システム }\end{array}$ \\
\hline 建設 & 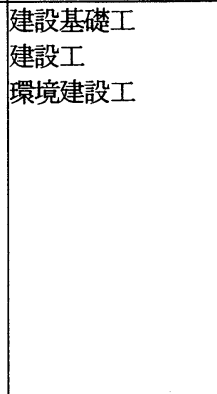 & \begin{tabular}{|l} 
建設工 \\
環境建設工 \\
土木建設工 \\
建設 \\
建設システム工 \\
建設環境工 \\
建設都市工 \\
社会建設工 \\
建設社会工 \\
安全システム建設工 \\
建築建設工
\end{tabular} \\
\hline
\end{tabular}

類数とキーワード数の差を重複キーワード数と呼ぶ。重 複キーワード数は、キーワードの多様性を示す指標であ る。すなわち、重複キーワード数が多いほど、同種類の キーワードを幾通りにも組み合わせて多様な学科名称を 作っていることを示している。例えば，「環境」

「土木」「建筑」等のキーワードを組み合わせて、「土木 環境」環境土木」「建築土木」「睘境建築」「建築環境 等の異なる学科名称をつくることができる。建設系の重 複キーワード数は、新制大学発足直後から第一次環境ブ 一ムまでは 1 ないし 3 の間であるが、第二次環境ブーム を通じて急増し、2000 年には 15 まで増加している(図一 6)。すなわち、第一次環境ブームには同じキーワードが 複数の学科名称に使われることは少なかったが、第二次 環境ブームにおいては同じキーワードが覑繁に異種類の 学科名称に使われていることとなる。

代表的なキーワードと学科名称の組み合わせを表 2 に 示す。第一次環境ブームには、環境」というキーワード を冠する学科名称の種類は 6 種類であり、「建設」という キーワードを冠する学科名称の種類は 3 種類であった。 第二次環境ブームには両者ともそれぞれ 11 種類まで増加 している。また、第二次環境ブームには、都市環境シス テム」安全システム建設工」のように、3 種類のキーワ 
ードを組み合わせた学科名称も出現した。また、両学科 名称で共通に用いられているキーワードは、第一次環境 ブームにおいては皆無であったが、第二次環境ブームに は「都市」「システム」「社会」土木」の4つとなってい る。

\section{(3)結び}

建設系学科の名称に着目して分析した結果、以下のよ うなことが明らかになった。

第一次環境ブームにおいては、キーワードの種類数に 比へ、学科名称の種類は少なく、結果として同じキーワ 一ドが何度も異なる学科名称に使われることは比較的少

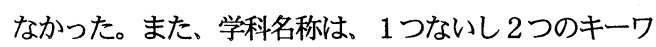
一ドから構成されていた。

第二次環境ブームには、建設系学科の名称のキーワー ド数が減少している。他方、3つのキーワードから成る 学科も出現するなジ、学科名称は多様化している。この ような中で、限られたキーワードを様々に組み合わせて、 多様な学科名称を作っている。そのため、必然的に、名 称の種類は増加し、しかも、限られた種類のキーワード が頻繁に使用されている。環境」は、その限定されたキ 一ワードの一つである。これを様々に組み合わせて多様 な学科名称を作っており、必然的に環境冠学科が増加し ている。

\section{5.結果}

以上のように、国立大学工学系学部の環境冠学科を、 工学系の拡大過程と科学研究の「ライフサイクル」論の 枠組みを用いて分析した。その結果、環境冠学科の設置 メカニズムには、工学系学科の学科構成や学科設置動向 を反映していることが明らかになった。従って、「環境】 あるいは「環境科学」という理念は、工学系学科の設置 のためのレトリックという側面を有しているように思わ れる。

\section{6. 考察}

1）学科名称のキーワードには、時代により流行がある。 地球環境問題の深刻化の中で、土木事業や建設産業にお いて環境に配慮することが必要とされ、土木技術者の地 球環境問題への貢献が訶われるようになった時代的潮流 の中で、「環境」は第二次環境ブームにおける流行のキー ワードとなっている。

2) 100 年程前に工部大学校に導入され、その後多くの日本 の高等教育機関の中で展開されてきた土木工学という学 問分野は、現在、転換期を迎えている。

内容面については、従来の構造力学、水理学、土質工 学をはじめとする土木工学のコアに、環境、情報、及び 社会科学との学際領域等、新たな枠組みが加わりつつあ
る。

また、土木工学という名称は、現在の学生からは古臭 いイメージを持たれがちで、あまり好まれなくなってき ているのも事実である。そして、18 歳人口の減少という 時代的背景の下で、大学側は、一つには学生獲得のため の戦略として、改組の際に、長い伝統をもつ土木工学と いう名称を廃止し、流行の学科名称へ衣替えをすること が、第二次環境ブームのトレンドになっている。

3) 日本の大学の学部・学科の名称は社会的背景に左右さ れており、環境冠学科も例外ではなかった。しかし、そ れだけでは学科は設置されず、高等教育政策とタイアッ プすることが必要条件であった。もし、公害問題や地球環 境問題に対する社会的関心が高揚した時期が 1970 年前後 や1980 年代後半以降ではなくて、1980 年代前半であった としたら、3 章で述べた高等教育計画の後期計画期と重な るため、環境冠学科の設置ラッシュは生じなかったと考 えられる。1970 年代半ば及び 1990 年代は、環境冠学科の 設置ラッシュが生じるにはちょうど良いタイミングであ つた。

4)このようなメカニズムが生じたのは，文部省の学部・ 学科の設置認可に起因していた。1 歳人口の減少や財政 難等の時代的背景のもとで、文部省は学部・学科の設置 を原則抑制としている。反面、特別な人材盖成や新分野 の開拓等、極めて必要性の高いものについては例外とし て新増設や改組転換を認めている ${ }^{16}$ 。 文部省の認可を得 るために、各大学は、大学の生き残り戦略として、特徵 のある学科をつくろうと努力をした。その結果、多様な 学科名称が出現した。しかも、文部省が認可しやすいキ ーワードは、「環境」「建設」「システム」等、時代の要請 にあった限定されたキーワードであった。総じて、第二 次環境ブームには、生き残れるためのキーワードが限定 される一方で、学科名称は多様にしないと生き残ること ができなかったのである。

5）従来、文部省の高等教育政策において、学部段階を中 心に政策が実施されていた。従って、博士課程の大学院 研究科を設置している大学においても、教官は学部に本 籍を置いていた。そして、学部組織の名称にはディシプ リン化は12された学問分野名が用いられ、ディシプリン化 されていない萌芽的な学問分野名は大学院組織において 初めて用いられるのが一般的であった注13)。しかし、1990 年代において国立大学の大学院重点化政策が実施され、 文部省の高等教育政策は大学院に重心を移すようになつ た。そのため、ディシプリン化されていない多様な学問 分野名が、学部段階の学科名称として多数出現するよう になった壮。この流れの中で、ディシプリンが未確立 ${ }^{17}$ の、多様な名称の環境冠学科が数多く設置されるように なった。 


\section{7. 結語}

以上のような設置メカニズムのために、環境冠学科の 教員の出身分野や教育内容がある程度限定されるものと 考えられる。

今後は、工学系の大学院、工学系を母体とした独立大 学院の動向についても同様な分析を行う。また、個々の 環境冠学科の教育・研究内容や、環境冠学科の教官の出 身分野等、多椂な角度から分析を行い、環境冠学科の内 容に踏み込んだ議論を行なう予定である。さらに、これ らの研究成果に基づいて、環境科学という学問分野のあ り方や、高等教育レベルの壊境教育の体系化についての 議論を行ないたい。最終的には、政策提言や個々の環境冠 学科の教育内容の改善に結びつける方向に研究を進める 予定である。

謝辞:本論文をまとめるにあたり、親身なご指導をくださ いました指導教官である東京大学教養学部の廣松毅教授、 筑波大学大学研究センターの佐野亮子助教授、及び 3 名 の查読者の方々に感謝致します。

\section{付録}

注1）日本環境教育学会及び大学史研究会において、環境冠学科 (器境を冠する学部・学科・大学院の総称)を取り上げたの は、1996 年の内山が最初である。なお、涠境冠学部」睘境 冠学科」という用語は内山による造語である。

注2）末石は、環境を接頭語とする学部・学科において睘境の研 究・教育がなされておらず、環境を芴盗しているという指摘

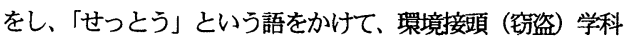
と呼んでいる。

注3）1996 年 4 月から 5 月にかけて、複数の国立大学の環境冠学 科の学生に満足度についてのインタビュ一調查を行なつた。 この結果は, 6) で報告した。

注4) 例えば、1970 年代に設立された A大学の環境冠学科では、

カリキュラムも卒業生の就職先も、母体学科のそれとほほ同 じであった ${ }^{18}$ 。

注5)ここで定義している建設系学科とは、土木系学科と建築系 学科の総称である。

注6）注 1)及び内山 ${ }^{19}$ において、環境冠学科の「看板 之内容の 非離」の問題をとりあげ、教職員 と学生に対するインタピュ 一を紹介している。

注7) 1996 年 5 月 12 日の日本環境教育学会大学環境教育ミニシ ンポジウムでの講演「大学における酸境教育の今日的特徴— 高等教育の視点から一」 ${ }^{20}$ において、1950 年代から1990年代 までの約 30 年間を、環境科学前史・第一次環境ブーム・第二 次環境ブームの 3 時代に区分した。

注8）1996 年 12 月 6 日の大学史研究会において、第一次環境ブ 一ムにおける国立大学工学系学部及び農学系学部の環境冠学 科の設置経衛についての分析を行つた。
注9）噮境科学会の設立当初から、環境科学という学問分野のあ り方について議侖がなされてきた。

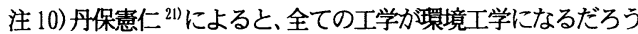
という予測をしている。

注 11) 例光ば、環境建設工学科と建設噮境工学科は、異種類の学 科名称として分類した。

注 12)ディシプリン化については、内山 ${ }^{22)}$ 中山 ${ }^{23)}$ を参照

注 13）主として独立大学院において、このような傾向がみられた。 筆者は、国立大学の独立大学院の研究科・尃攻における萌芽 的な学問分野名の分析について、1999 年 9 月 30 日の教育社会 学会大会でとりあげている ${ }^{24)}$

注 14) 2002 年 4 月 26 日、金沢工業大学 STSP 研究会における筆 者の講演「環境科学の制度化」に対する手塚晃によるコメン 卜

\section{参考文献}

1) 末石富太郎 : 環境学部のあるべき姿、第 23 回噮境システム研 究論文発表会シンポジウム講寅集，1995.

2)沼田眞: 訳者あとがき，ワット，沼田眞訳、環境科学, 東海大 出版会, p. 297, 1975.

3) 橋本道夫: 鲏境科学の生成, 睘境科学会誌, vol. 1, No. 1, pp. 11-12, 1988.

4）末石富太郎 : 環境学部のあるべき姿、第 23 回環境システム 研究論文発表会シンポジウム講演集，1995.

5）荒井克弘:マンパワ一政策と理工系大学教育の抗大，中山茂 編, 通史日本の科学技術, 学陽書房, vol. 3, pp. 81-94, 1995.

6) 才律靖 - 矢野真和:工学系教育の挔大過程之高等教育政策,学 習社会におけるマス高等教育の構造と機能に関する研究, 放 送教育開発センター, pp. 228-243, 1996.

7) 関正夫:日本の大学教育改革一歴史 - 現状 - 展望，玉川大学出 版部, 1988.

8) 山田圭一, 塚原修: 科学研究のライフサイクル, 東京大学出 版会, pp. 1-20, 1986.

9) 文部省:大学資料，47，p. 31，1973.

10) 黒田勝彦, 和田安彦:土木工学概論, 共立出版, pp. 242-244, 1998.

11) 橋本道夫:グローバル・シビルエンジニアリングの系譜, 土 木学会誌４月号別冊增刊, pp. 36 - 40, 1994.

12) 宗宮功: 衛生工学研究力ら環境工学へ、土木学会論文集, VII -14, pp. 1-10, 2000.

13) 文部省: 理工系学生 8000 人增員計画実施内訳, 文部省第 88 年報昭和 35 年度, p. $16,1960$.

14)文部省:理工系学生 2 万人增員計画, 大学資料, 22, pp. 69-70, 1967.

15) 才津靖 - 矢野真和:工学系教育の抁大過程之高等教育政策,学 習社会におけるマス高等教育の構造と機能に関する研究, 放 送教育開発センター, pp. 228-243, 1996.

16) 高等教育研究会: 大学設置審查要覧, 文教協会, p. 117, 1999 
17) 内山弘美: 環境科学の制度化と大学教育一睘境冠学科をめぐ ってー, 特集睘境科学シンポジウム 1999、曼境科学会 誌, vol. 13, No. 1, pp. 95-98, 2000.

18) 内山弘美: 襄境科学の形成と展開, 中山茂編, 通史日本の科学 技術, 学陽書房, vol. 5, No. 2, pp. 600-610, 1999a.

19）内山弘美:再び大学における環境教育とは, STSNJ ニュースレ ター, vol.9, No.1, pp.10-11, 1998.

20) 内山弘美:再び大学における環境教育とは, STSNJニュースレ ター, vol.9, No.1, pp.10-11, 1998.

21）丹保憲仁：睘境衛生工学の回顧と展望, 土木学会論文集,

No. 552/VII, pp. 1-20, 1996.
22）内山弘美:環境科学の制度化と大学教育一環境冠学科をめぐ って一, 特集環境科学シンポジウム 1999、環境科学会誌, vol. 13, No. 1 No., pp. 95-98, 2000.

23）中山茂: 市民のための科学論、 1984.

24）内山弘美:圜境科学のディシプリンと大学, 教育社会学会大 会要旨集, $1999 \mathrm{~b}$.

\section{THE ESTABLISHMENT MECHANISM OF ENVIRONMENT-RELATED DEPARTMENTS IN JAPANESE NATIONAL UNIVERSITIES, FOCUSING ON DEPARTMENTS RELATED TO ITS CONSTRUCTION -FROM THE VIEWPOIT OF HIGHER EDUCATION POLICY-}

\section{HIROMI UCHIYAMA}

In order to solve the global environmental problems and to create a sustainable society, it is necessary to establish the environmental science as an interdisciplinary science. One of the indices of the institutionalization of the environmental science is the environment-related departments in universities. Because the discipline of environmental science has not been well established yet, there is a gap between ideals and realities about research and education in these departments. One of the factors that caused the gap is the way these departments were established. The purpose of this paper is to scrutinize the mechanism of the establishment of environment-related departments, focusing on departments related to Construction (e.g. the department of civil engineering, the department of architecture, etc.). As a result, the higher education policy as well as efforts of establishment of the environmental science turns out to be one of the most important factors to the establishment mechanism of environment-related departments. 